\title{
Freshwater ecotoxicity impacts from pesticide use in animal and vegetable foods produced in Sweden
}

\author{
Maria Nordborg ${ }^{\mathrm{a}, *}$, Jennifer Davis ${ }^{\mathrm{b}}$, Christel Cederberg ${ }^{\mathrm{a}}$, Anna Woodhouse ${ }^{\mathrm{b}}$ \\ ${ }^{a}$ Department of Energy and Environment, Chalmers University of Technology, SE-412 96 Gothenburg, Sweden \\ b SP Technical Research Institute of Sweden, Food and Bioscience, SE-402 29 Gothenburg, Sweden
}

\section{H I G H L I G H T S}

- Animal-based food products have much larger impacts than plant-based food products.

- Impact potentials per $\mathrm{kg}$ pork $>$ chicken $>$ beef $>$ milk $>$ bread $>$ pea soup.

- Chicken fillet and minced pork have larger impacts than minced beef and milk.

- Soybeans dominate the impact potentials of chicken fillet and minced pork.

- Replacing soybeans with local feed crops can reduce the impacts considerably.

\section{A R T I C L E I N F O}

\section{Article history:}

Received 30 October 2016

Received in revised form 20 December 2016

Accepted 22 December 2016

Available online $\mathrm{xxxx}$

Editor: D. Barcelo

\section{Keywords:}

Freshwater ecotoxicity

Food

Pesticides

USEtox

PestLCI

Soybeans

\section{GRA P H I C A L A B S T R A C T}

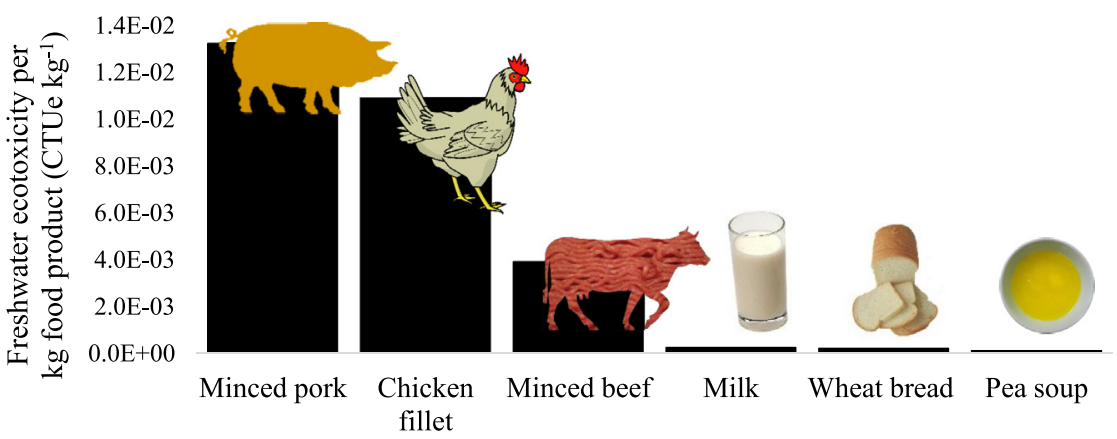

\begin{abstract}
A B S T R A C T
Chemical pesticides are widely used in modern agriculture but their potential negative impacts are seldom considered in environmental assessments of food products. This study aims to assess and compare the potential freshwater ecotoxicity impacts due to pesticide use in the primary production of six food products: chicken fillet, minced pork, minced beef, milk, pea soup, and wheat bread. The assessment is based on a detailed and site-specific inventory of pesticide use in the primary production of the food products, all of which are produced in Sweden. Soybeans, used to produce the animal-based food products, are grown in Brazil. Pesticide emissions to air and surface water were calculated using PestLCI v. 2.0.5. Ecotoxicity impacts were assessed using USEtox v. 2.01 , and expressed in relation to five functional units. The results show that the animal-based food products have considerably larger impact potentials than the plant-based food products. In relation to kg pea soup, impact potentials of bread, milk, minced beef, chicken fillet and minced pork are ca. 2, 3, 50, 140 and 170 times larger, respectively. All mass-based functional units yield the same ranking. Notably, chicken fillet and minced pork have larger impacts than minced beef and milk, regardless of functional unit, due to extensive use of pesticides, some with high toxicity, in soybean production. This result stands in sharp contrast to typical carbon footprint and land use results which attribute larger impacts to beef than to chicken and pork. Measures for reducing impacts are discussed. In particular, we show that by substituting soybeans with locally sourced feed crops, the impact potentials of minced pork and chicken fillet are reduced by ca. 70 and $90 \%$, respectively. Brazilian soybean production is heavily reliant on pesticides. We propose that weak legislation, in combination with tropical climate and agronomic practices, explains this situation.
\end{abstract}

C 2016 Published by Elsevier B.V.

\footnotetext{
* Corresponding author.

E-mail address: maria.nordborg@gmail.com (M. Nordborg).
} 


\section{Introduction}

Globally, the planetary boundaries that define the safe operating space for humanity have been transgressed for biodiversity loss (Rockström et al., 2009). According to the review by Diamond et al. (2015), there is sufficient evidence to say that also the safe operating space for chemical pollution has been transgressed. Agricultural chemicals, such as pesticides, contribute to these boundary transgressions, although it is not known to which extent. Pesticides provide many benefits but also have negative effects. Studies have, e.g., linked agricultural chemicals to surface water pollution (Stehle and Schulz, 2015) and to negative impacts on bird populations in agricultural landscapes (Hallmann et al., 2014), survival and growth of bee colonies (Whitehorn et al., 2012, Henry et al., 2012), biodiversity (Geiger et al., 2010, Beketov et al., 2013), and ecosystem functions (Schäfer et al., 2007).

Life cycle assessment (LCA) is one of the most commonly used methods for assessing the potential environmental impacts associated with a product or a service throughout its life cycle. Despite the fact that chemical pesticides are integral parts of modern food production systems, their ecotoxicity impacts are often not considered in LCA-studies of food products (Henriksson et al., 2012, de Vries and de Boer, 2010, Nemecek et al., 2016). One important reason is the lack of high-quality inventory data of pesticide use and emissions (Yang and Suh, 2015). When pesticides are included, emission inventories often rely on oversimplified assumptions, are not site-specific, and suffer from methodological inconsistencies (Rosenbaum et al., 2015, van Zelm et al., 2014).

In LCA, all impacts are expressed in relation to a functional unit that intends to capture the primary function of the assessed product (JRC, 2010). Despite this, although nutrition can be considered the primary function of food, LCA studies of food products usually only assess impacts in relation to the mass of food (de Vries and de Boer, 2010, Schau and Fet, 2008, Henriksson et al., 2012, Roy et al., 2009, Nijdam et al., 2012). Sonesson et al. (2017) developed a range of new functional units based on the quality and/or quantity of protein, as well as the dietary context. Functional units that take protein quality and/or quantity into account are interesting since proteins are essential nutrients and associated with widely different environmental impacts depending on origin and production method.

A relatively large number of studies have assessed the carbon footprints and land use of different protein sources. Generally, proteins of animal origin (especially ruminant meat) require more resources, including land, and have larger carbon footprints, than proteins of vegetable origin (Nijdam et al., 2012, Aiking, 2014, Nemecek et al., 2016, Wirsenius et al., 2010). For meat products, carbon footprints and land use generally decrease in the order beef $>$ pork > poultry (Westhoek et al., 2011, Nijdam et al., 2012).

The aim of this study is to assess and compare the potential freshwater ecotoxicity impacts due to pesticide use in the primary production of six food products of animal and vegetable origin (chicken fillet, minced pork, minced beef, milk, pea soup and wheat bread). Since the choice of functional unit can have a large influence on results and conclusions, impacts are assessed in relation to five different functional units: $\mathrm{kg}$ food, food energy content, and three functional units that take protein quantity and/or quality into account. Ultimately, this study aims to contribute to more comprehensive and relevant environmental assessments of food products.

\section{Method}

This study uses LCA methodology to assess the potential freshwater ecotoxicity impacts from pesticide use in the primary production of a selection of food products. Primary production refers to the cultivation of the crops on which the assessed food products are based (whether directly or as animal feed). The food products are presented in Section 2.1.
The method applied here consists of four steps. First, we conducted a detailed and site-specific inventory of the pesticide use and emissions in the studied crops and regions (Section 2.2). Second, we calculated the potential freshwater ecotoxicity impacts per $\mathrm{kg}$ harvested crop (Section 2.3). Third, we calculated the potential freshwater ecotoxicity impacts per kg food product using a model of Swedish food production systems (Section 2.4). Finally, impact scores were expressed in relation to a selection of five different functional units (Section 2.5).

\subsection{Food products, crops and study regions}

Six food products, based on eight crops, are included here (Table 1). Four food products are of animal origin, and two are of vegetable origin. The food products are produced in the county of Västra Götaland, in the southwest part of Sweden. Seven of the crops are produced in Västra Götaland and one (soybean) is produced in Mato Grosso, Brazil (Table 2). In Västra Götaland, we differentiate between a plain region, characterized by relatively intensive crop production in a flat landscape, and a mixed landscape region, characterized by a mix of forests, permanent pastures, and arable lands with a mix of crop and grass production (for more information, see Chapter S1 in the Supporting Information). Mato Grosso, Brazil, represents a region with large-scale and intensive soybean production. Soil, climate, and field conditions differentiate the regions (for more information, see Chapters S3-S5 in the Supporting Information).

\subsection{Life cycle inventory}

The life cycle inventory consists of two parts, both of which are sitespecific: pesticide application inventory (Section 2.2.1) and pesticide emission inventory (Section 2.2.2).

\subsubsection{Pesticide application inventory}

The crops are part of specific crop rotations (Table 2), which partly determine the need for pesticide input. For all crops except peas and soybean, pesticide application data were obtained from Sonesson et al. (2014), which compiled information about current agronomic practices in the studied crops and regions, see also SLU (2015). Glyphosate, one of the most commonly used active substances in Sweden (KemI, 2014), was added to the pesticide application data obtained from Sonesson et al. (2014), in order to increase the representativeness of the application scenarios. Pesticide application data for peas were determined based on information from the Swedish Board of Agriculture (SJV, 2015a, SJV, 2015b).

Pesticide application data for soybeans were obtained from the conventional soybean case (soybeans not genetically engineered to tolerate glyphosate) in Nordborg et al. (2014). We considered conventional soybeans, although a majority of soybeans produced in Brazil are genetically engineered to tolerate glyphosate and hence subject to larger amounts of pesticides (in particular glyphosate) than conventional soybeans, see Nordborg et al. (2014). However, there is no significant difference in the potential freshwater ecotoxicity impacts between conventional and genetically engineered glyphosate tolerant soybeans, since insecticides and fungicides, which are used regardless of seed technology, dominate the impact scores (Nordborg et al., 2014).

The pesticide application data represent current, typical, and realistic use of pesticides in the studied crops and regions and specify, for

Table 1

The food products considered here, and the underlying crops.

\begin{tabular}{ll}
\hline Food products & The crop(s) required to produce the food product \\
\hline Wheat bread & Bread wheat \\
Pea soup & Field peas \\
Minced pork & Feed wheat, rapeseed, soybeans, oats, barley \\
Milk & Grass/clover ${ }^{\text {a }}$, oats, barley, soybeans \\
Minced beef & Grass/clover ${ }^{\text {a }}$, oats, barley, soybeans \\
Chicken fillet & Feed wheat, rapeseed, soybeans \\
\hline
\end{tabular}

a A mix of grass and clover is fed to dairy cows and beef cattle in the form of silage. 
Table 2

The crops considered here and their production regions and yields. Information about crop rotations (see table footnotes) were obtained from Sonesson et al. (2014) and represent current agronomic practices in the studied regions.

\begin{tabular}{lll}
\hline Crops & Production regions & $\begin{array}{l}\mathrm{Crop} \mathrm{yields}^{\mathrm{a}} \text { (tonne ha }^{-1} \\
\mathrm{yr}^{-1} \text { ) }\end{array}$ \\
\hline Rapeseed $^{\mathrm{b}}$ & Plain region, Västra Götaland, Sweden & 3.4 \\
Feed wheat $^{\mathrm{b}}$ & Plain region, Västra Götaland, Sweden & 6.0 \\
Bread wheat $^{\mathrm{c}}$ & Plain region, Västra Götaland, Sweden & 6.5 \\
Barley $^{\mathrm{b}}$ & Plain region, Västra Götaland, Sweden & 4.7 \\
Oats $^{\mathrm{b}}$ & Plain region, Västra Götaland, Sweden & 4.5 \\
Grass/clover $^{\mathrm{d}}$ & Mixed landscape region, Västra & $10.0 / 7.0^{\mathrm{f}}$ \\
& Götaland, Sweden & \\
Peas & Plain region, Västra Götaland, Sweden & 3.2 \\
Soybean & Mato Grosso, Brazil & 3.1 \\
\hline
\end{tabular}

a Cereal grain yields refer to the mass of harvested crops (14\% water content). Grass/ clover yields refer to the mass of dry matter. Rapeseed yields refer to the mass of harvested seeds. Yields for crops produced in Sweden were obtained from Sonesson et al. (2014). The soybean yield refers to the mass of harvested seeds ( $13 \%$ water content) and represents the average yield between 2008 and 2012 in Mato Grosso, Brazil, calculated based on information from the Brazilian Institute of Geography and Statistics (SIDRA-IBGE).

b Included in the following crop rotation (8 years) on a pig/chicken production farm: winter wheat - oats -winter wheat - broad beans - oats - winter wheat - spring barley winter rapeseed.

${ }^{c}$ Included in the following crop rotation ( 4 years) on a crop production farm: winter wheat - oats - winter wheat - spring barley.

d Grass mixed with clover for silage production, established for three years in rotation with cereals on a dairy milk and beef production farm.

e Peas were not included in any of the reference crop rotations in Sonesson et al. (2014). We assumed that peas are included in a similar crop rotation - and subject to similar treatment and field operations - as broad beans.

f Year 1 and $2 /$ Year 3.

each application event, the type of pesticide (herbicide, fungicide, or insecticide), brand name of the pesticide product, active substance, dose of pesticide product per application, active substance content in the pesticide product, frequency of application, applied dose of active substance per application, average dose of active substance per hectare and year, crop type and development stage at time of application, method of application, tillage type at time of application, and application month. Frequency of application represents the fraction of a field treated in a year, or the variation in treatment between years. For example, an application frequency of 0.25 means that a quarter of the field is treated every year, or that the entire field is treated every fourth year. Yearly average pesticide application rates in the studied crops and regions are presented in Fig. 1. Detailed information about the pesticide application data is available in Chapter S2 in the Supporting Information.

\subsubsection{Pesticide emission inventory}

Pesticide emissions were calculated using an extended, updated, and site-specific version of the pesticide emission model PestLCI v. 2.0.5 (Dijkman et al., 2012). This model, which is implemented in Analytica (Lumina Decision Systems, Inc), has been described as the most advanced pesticide emission inventory model currently available, for use in agricultural LCAs (Van Zelm et al., 2014). PestLCI takes into account the physico-chemical properties of pesticides (e.g., degradation rates), local field conditions (e.g., slope), pedoclimatic conditions at the time and place of application (e.g., air temperature and soil clay content), and agronomic practices (e.g., tillage type). Detailed information about how these parameters were set in each crop and region is available in Chapters S3 (field data), S4 (soil data) and S5 (climate data) in the Supporting Information. All physico-chemical parameters considered in PestLCI are listed in Chapter S6 in the Supporting Information.

PestLCI regards the agricultural field (defined as a field-box extending $1 \mathrm{~m}$ down into the soil column and $100 \mathrm{~m}$ up into the air column) as part of the "technosphere," and estimates the mass of pesticide active substance emitted from the field to the surrounding environment, following field application. PestLCI estimates emissions to three

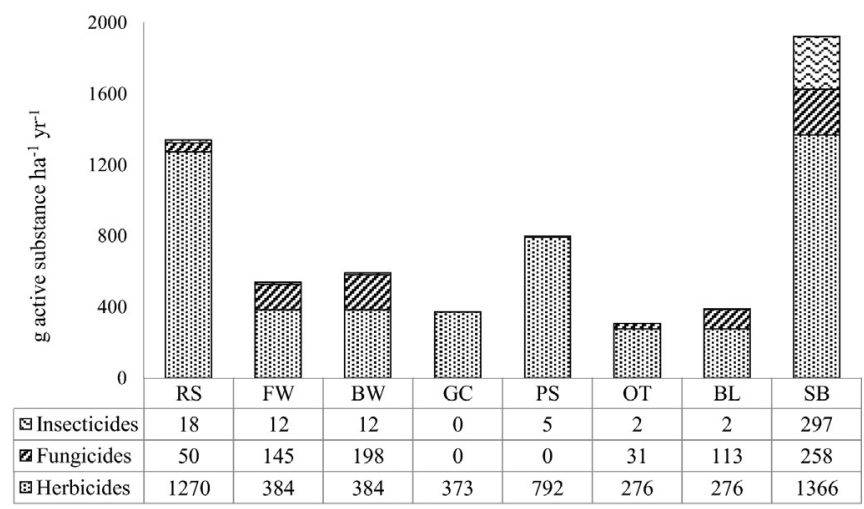

Fig. 1. Yearly average pesticide application rates, based on application data presented in Chapter S2 in the Supporting Information, and the distribution between herbicides, fungicides, and insecticides. $\mathrm{RS}=$ rapeseed, $\mathrm{FW}=$ feed wheat, $\mathrm{BW}=$ bread wheat, $\mathrm{GC}=$ grass $/$ clover, $\mathrm{PS}=$ peas, $\mathrm{OT}=$ oats, $\mathrm{BL}=$ barley, $\mathrm{SB}=$ soybean

environmental compartments: air, surface water, and ground water. Here, we account for emissions to air and surface water, since characterization factors (see Chapter 2.3) are not available for emissions to ground water.

For example, to calculate the emissions from the use of glyphosate in rapeseed, we selected glyphosate in the PestLCI model, entered the dose per application (1.08 $\mathrm{kg} \mathrm{ha}^{-1}$ of active substance), and adjusted all model parameters (month, soil type, climate, method of application, etc.) to conditions in the plain region of Västra Götaland, Sweden. As a result, PestLCI returned the emissions to air and surface water: $8.5 \mathrm{E}-04$ and $4.9 \mathrm{E}-04 \mathrm{~kg} \mathrm{ha}^{-1}$, respectively. Screenshots of the model (input and output screens) are available in Chapter S7 in the Supporting Information.

The version of PestLCI used here is based on a previously extended version of PestLCI v. 2.0.5, developed and used in Nordborg et al. (2014). In addition to previously made extensions, we developed two new soil profiles that represent conditions in the plain and the mixed landscape regions in Västra Götaland, Sweden, based on data from the Swedish Agricultural Soil Inventory (http://www-jordbruksmark.slu. se/). We also developed a new climate profile to represent conditions in Västra Götaland. For Brazil, we used soil and climate profiles developed and used in Nordborg et al. (2014). Further, the modeling of wind drift was updated in response to new knowledge, and errors in the modeling of biodegradation in soil were corrected, with support from the PestLCI development team. More information about the modeling of pesticide active substances is available in Chapter S7 in the Supporting Information.

\subsection{Freshwater ecotoxicity impact assessment in crop production}

USEtox version 2.01 (www.usetox.org, Fantke et al., 2015a, Rosenbaum et al., 2008), released in February 2016, was used to calculate the potential freshwater ecotoxicity impacts due to pesticide use. USEtox is an emission route-specific impact assessment model developed in a "scientific consensus" process that "merged" several toxicity impact assessment models (Hauschild et al., 2008). USEtox is generally recognized as the most advanced model currently available for comparative assessment of chemicals and their toxic effects on humans and freshwater ecosystems (see, e.g., Hauschild et al., 2013) and is recommended by several influential organizations and authorities (Fantke et al., 2015a).

In LCA, characterization factors quantify the relative contribution from each unit emission to a given impact category (JRC, 2010). USEtox, which is implemented in Excel, uses matrix algebra and a nested model structure that integrates two spatial scales (continental and global) to calculate characterization factors for emissions to different environmental compartments. We used site-generic characterization factors 
at midpoint level that represent estimates of the Potentially Affected Fraction (PAF) of species in (freshwater) space and time per unit emission. The characterization factors are measured in the unit Comparative Toxic Unit ecotoxicity (CTUe) per $\mathrm{kg}$ emitted substance, where 1 $\mathrm{CTUe}=\mathrm{PAF} \mathrm{m}^{3}$ day. Characterization factors are based on landscape data that represent an average default continent (i.e., not any specific country or region), and have an estimated uncertainty range that spans 1-2 orders of magnitude (Rosenbaum et al., 2008). All characterization factors are available in Chapter S8 in the Supporting Information.

In LCA, impact scores are calculated as the product of environmental emissions and characterization factors, summed over all emission compartments and substances. Potential freshwater ecotoxicity impacts per $\mathrm{kg}$ harvested crop (CTUe $\mathrm{kg}^{-1}$ ) were calculated as the yearly average potential freshwater ecotoxicity impact per hectare cropland (CTUe $\left.\mathrm{ha}^{-1} \mathrm{yr}^{-1}\right)$, divided by the yearly average crop yield $\left(\mathrm{kg} \mathrm{ha}^{-1} \mathrm{yr}^{-1}\right)$. Yearly average potential freshwater ecotoxicity impacts per hectare cropland were calculated as the product of emissions and freshwater ecotoxicity characterization factors, according to Eq. (1), where $e_{a i r, P}$ and $e_{\text {water }, P}$ denote the mass of pesticide $P$ emitted to air and surface water $\left(\mathrm{kg} \mathrm{ha}^{-1}\right)$, respectively, $C F_{a i r, P}$ and $C F_{\text {water }, P}$ denote the midpoint freshwater ecotoxicity characterization factors of pesticide $P$ for emissions to rural air at the continental scale, and freshwater at the continental scale (CTUe $\mathrm{kg}^{-1}$ ), respectively, and $f_{P}$ denotes pesticide $\mathrm{P}^{\prime} \mathrm{S}$ application frequency $\left(\mathrm{yr}^{-1}\right)$.

\section{Potential freshwater ecotoxicity impact of pesticide $P$$$
=\left(e_{\text {air }, P} \cdot C F_{\text {air }, P}+e_{\text {water }, P} \cdot C F_{\text {water }, P}\right) \cdot f_{P}
$$

For example, to calculate the potential freshwater ecotoxicity impacts associated with the use of glyphosate in rapeseed, we multiplied the emissions of glyphosate to air and surface water $(8.5 \mathrm{E}-04$ and $4.9 \mathrm{E}-04 \mathrm{~kg} \mathrm{ha}^{-1}$, respectively) with the characterization factors of glyphosate for emissions to air and freshwater (10 and $321 \mathrm{CTUe} \mathrm{kg}^{-1}$, respectively) and the frequency of application $\left(0.25 \mathrm{yr}^{-1}\right)$. The resulting impact potential is 0.04 CTUe ha $^{-1} \mathrm{yr}^{-1}$ (see also Table S13.1 in the Supporting Information).

Some of the pesticides identified during inventory were not available in the USEtox 2.01 database. For these - in total 9 active substances - we calculated new characterization factors. Physico-chemical and ecotoxicological effect data required to calculate new characterization factors were collected in line with the procedure described in Fantke et al. (2015b), with some modifications in order to create a more consistent physico-chemical dataset between PestLCI and USEtox. The physico-chemical data that PestLCI and USEtox use are, currently, based on the recommendations from the respective development teams, derived from different data sources, which has previously been identified as problematic (Nordborg et al., 2014). USEtox uses EPISuite as the default database for physico-chemical data. We derived physico-chemical data primarily from the Pesticide Properties Database (PPDB), since experimental, quality controlled, and verified data from PPDB were considered to likely be more accurate than estimated data from EPISuite. Also, PPDB is the default database for which PestLCI derives data. More information about USEtox, and how we calculated new characterization factors, including a screenshot of the model, is available in Chapters S9-S11 in the Supporting Information.

\subsection{Assessment of impacts per $\mathrm{kg}$ food product}

Potential freshwater ecotoxicity impacts per $\mathrm{kg}$ food product were calculated based on impact scores per kg harvested crop, using an LCA model of Swedish food production systems. The model calculates the mass of crops required per $\mathrm{kg}$ food consumed in the household, using representative conversion efficiencies in the assessed production systems (animal rearing, slaughter, milling, bakery, cooking, etc.). For the animal-based food products, conversion efficiencies are based on typical feed rations in the studied regions. Different feed rations for different animal categories were used in the model (e.g., dairy cows, suckler cows, calves, heifers, bulls, etc., in the beef-production system). Table 3 presents the average feed rations for the whole production systems.

For wheat bread and pea soup, conversion efficiencies are based on typical recipes used in the Swedish food industry. For example, $1 \mathrm{~kg}$ wheat bread consumed in the household requires $0.82 \mathrm{~kg}$ of bread wheat from the field. Loss of water during cooking is also considered. For example, $1 \mathrm{~kg}$ of cooked beef requires $1.25 \mathrm{~kg}$ of raw beef. It is assumed that no food goes to waste along the supply-chain, nor in the household. The LCA model and the data on which it is based are further described in Sonesson et al. (2014).

In the primary production of the studied food products, i.e., in crop cultivation, the potential freshwater ecotoxicity impacts associated with the use of pesticides were fully allocated to the assessed crops, since no co-products are produced at this stage. Some of the crops, however, are associated with co-products at later stages in their life-cycles (e.g., at the mill). These co-products were accounted for in the LCA model of the food production systems. Economic allocation was used to allocate between flour, bran and wheat feed at the mill, and between milk and meat at the dairy farm. No environmental load was allocated to straw. To allocate between the different meat products at the slaughterhouse, however, mass allocation was used, since it is not possible to change the composition of the animal to maximize the economic profit.

\subsection{Functional units}

We assessed impacts in relation to five functional units: food mass $(\mathrm{kg})$, food energy content (Mcal), and three functional units that take protein quantity and/or quality into account. Data on food energy content were obtained from the Swedish Food Composition Database (see Chapter S12 in the Supporting Information), except for minced pork (pan-fried minced pork with 15\% fat), which was not available. For pan-fried minced pork with $15 \%$ fat, we estimated the energy content, assuming the same relation between fresh and pan-fried minced pork with $15 \%$ fat, as between fresh and pan-fried minced beef with $10 \%$ fat. The resulting estimate was checked against the Dutch food database NEVO (http://nevo-online.rivm.nl/).

The protein-based functional units are "kg protein," and the newly developed functional units "kg digestible protein" and "kg PQI-adjusted food (AD)," where PQI stands for protein quality index, and AD stands for average Swedish diet (Sonesson et al., 2017). The functional unit "kg protein" is based on the share of protein per kg food. The functional unit "kg digestible protein" is based on the share of protein per $\mathrm{kg}$ food and the share of digestible protein (using data on faecal digestibility). For example, legumes have lower digestibility than meat.

The PQIs are dimensionless coefficients developed based on the composition of nine essential amino acids in the food product, the true ileal digestibility of each amino acid in single food products, the composition of the amino acids in the total dietary intake, and the nutritional requirements for the amino acids. The PQIs are thus dependent on the dietary context: the higher the PQI, the more valuable the product in a given diet. The idea is that products with a higher nutritional value (in

Table 3

Average feed rations in the animal-based food production systems considered here. The feed rations include feed consumed by all animal categories in the production systems.

\begin{tabular}{lllll}
\hline Feed ingredients & \multicolumn{3}{l}{$\begin{array}{l}\text { Consumed feed in kg per kg food product consumed in the } \\
\text { household }\end{array}$} \\
\cline { 2 - 5 } & Milk & Minced beef & Minced pork & Chicken fillet \\
\hline Rapeseed & & & 0.7 & 0.2 \\
Feed wheat & & & 2.6 & 2.5 \\
Barley & 0.1 & 1.5 & 2.9 & \\
Oats & 0.1 & 1.5 & 1.2 & 1.0 \\
Grass/clover & 0.5 & 8.4 & & 3.7 \\
Soybeans & $<0.1$ & 0.1 & 0.8 & \\
Total & 0.7 & 11.5 & 8.2 & \\
\hline
\end{tabular}


relation to the dietary supply) will get more favorable LCA results (i.e., lower environmental impacts) and vice versa. Sonesson et al. (2017) developed PQIs for three Swedish diets with different supplies of protein, but found that the dietary context was of little importance when ranking food products in terms of environmental impact. Therefore, only PQIs for one of the diets, AD, was included here. However, as pointed out in Sonesson et al. (2017), the dietary context is probably more relevant in protein-poor diets.

Impact potentials expressed in relation to " $\mathrm{kg}$ PQI-adjusted food (AD)" were calculated by dividing impact potentials expressed in relation to "kg food" by the PQI-coefficients, transforming a physical mass flow ( $\mathrm{kg}$ ) to a fictitious mass flow (PQI-weighted $\mathrm{kg}$ ). Therefore, the impact potentials expressed in relation to "kg PQI-adjusted food (AD)" should primarily be used to rank products, since the absolute values are difficult to interpret in terms of actual impacts. For more information about the PQI, and the diets, see Sonesson et al. (2017). For more information about how impact scores in CTUe per $\mathrm{kg}$ food product were converted to impact scores in relation to the other functional units, and the data used, see Chapter S12 in the Supporting Information.

\section{Results}

Section 3.1 presents the potential freshwater ecotoxicity impacts per $\mathrm{kg}$ harvested crop in primary production. Section 3.2 presents the potential freshwater ecotoxicity impacts per $\mathrm{kg}$ food product and the contributions from crops on which the food products are based. Section 3.3 presents the potential freshwater ecotoxicity impacts of food products relative different functional unit. Section 3.4 analyses and explains the observed differences among the food products.

\subsection{Ecotoxicity impacts in primary production}

Fig. 2 shows the potential freshwater ecotoxicity impacts in CTUe per $\mathrm{kg}$ harvested crop, and the contributions from herbicides, fungicides, and insecticides. There is a large variation in impact scores between the crops, by up to 3 orders of magnitude. In relation to grass/ clover, which has the smallest impact potential per kg harvested crop, feed wheat, bread wheat, peas, rapeseed, oats, barley, and soybeans have impact potentials that are 18, 19, 25, 43, 76, 91 and 1159 times larger, respectively.

The impact potentials of pesticides used in peas, oats, soybeans and barley are dominated by insecticides, in wheat (both types) by fungicides and in rapeseed and grass/clover by herbicides. In most crops, only a single or a few active substances dominate the impact potentials, see Chapter S13 in the Supporting Information.

\subsection{Ecotoxicity impacts per $\mathrm{kg}$ food product}

Fig. 3 shows the potential freshwater ecotoxicity impacts in CTUe per $\mathrm{kg}$ food product, and the contributions from crops on which the food products are based. In relation to pea soup, which has the smallest impact potential per $\mathrm{kg}$ food, bread, milk, minced beef, chicken fillet and minced pork have 2, 3, 50,138 and 168 times larger impact potentials, respectively.

Notably, pesticides used in soybean production dominate the impact potentials of chicken fillet and minced pork, contributing 95\% of the impact potential of chicken fillet (wheat and rapeseed contribute the remaining $5 \%$ ), and $66 \%$ of the impact potential of minced pork (barley contributes another $21 \%$, and other crops contribute the remaining $13 \%)$. For minced beef, $40 \%$ of the impact potential is attributed to barley (i.e., to pesticides used in production of barley), $32 \%$ to oats, $24 \%$ to soybeans, and the remaining $4 \%$ to grass/clover. For milk, $39 \%$ of the impact potential is attributed to barley, $32 \%$ to oats, $27 \%$ to soybeans, and the remaining $2 \%$ to grass/clover.

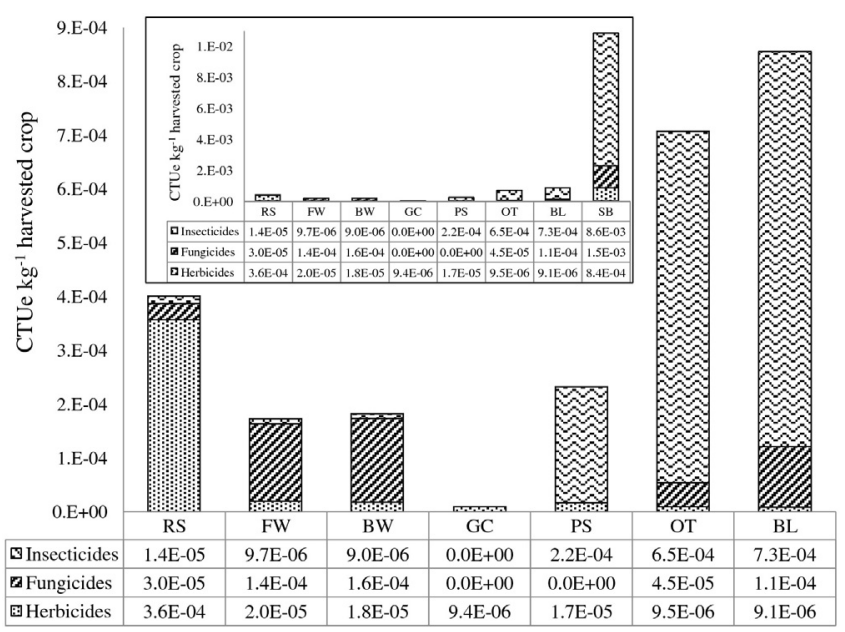

Fig. 2. Potential freshwater ecotoxicity impacts in CTUe (Comparative Toxic Units ecotoxicity) per kg harvested crop, and the distribution between herbicides, fungicides, and insecticides. Soybean is excluded due to its dominance, but is included in the smaller, inserted figure. $\mathrm{RS}=$ rapeseed, $\mathrm{FW}=$ feed wheat, $\mathrm{BW}=$ bread wheat, $\mathrm{GC}=$ grass/clover, $\mathrm{PS}=$ peas, $\mathrm{OT}=$ oats, $\mathrm{BL}=$ barley, $\mathrm{SB}=$ soybean.

\subsection{Ecotoxicity impacts of food products across functional units}

Fig. 4 shows the potential freshwater ecotoxicity impacts of food products in CTUe per functional unit, relative to minced pork. Results are shown relative to pork since we are primarily interested in how the different functional units rank the food products, and since the functional unit "kg PQI-adjusted food (AD)" represents a fictitious mass flow, rendering the absolute values difficult to interpret in terms of actual impacts and non-comparable to impact potentials expressed in relation to functional units that represent physical mass flows.

All mass-based functional units yield the same ranking of the food products: impact potentials decrease in the order minced pork $>$ chicken fillet $>$ minced beef $>$ milk $>$ bread $>$ pea soup. In relation to food energy content, chicken fillet scores higher than pork, since the energy density (Mcal kg ${ }^{-1}$ ) of chicken fillet is $25 \%$ lower than of minced pork (see Chapter S12 in the Supporting Information), hence less valuable from an energy perspective.

The plant-based food products, pea soup and wheat bread, have considerably smaller impact potentials than the animal-based food products: $<5 \%$ of the impact potential of chicken fillet across the different functional units.

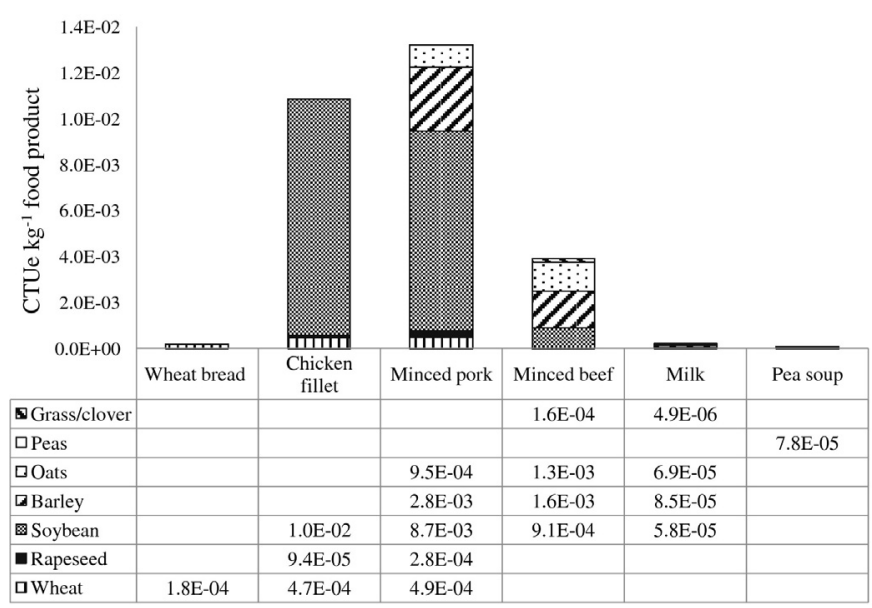

Fig. 3. Potential freshwater ecotoxicity impacts in CTUe (Comparative Toxic Units ecotoxicity) per kg food product, and the contributions from crops on which the food products are based. 
Notably, beef scores lower than minced pork and chicken fillet, regardless of functional unit, i.e., impacts attributed to pesticides used in feed production for beef are smaller than impacts attributed to pesticides used in feed production for chicken and pork. This result stands in sharp contrast to typical carbon footprint and land-use results for meat products (see Table 4), which attribute larger impacts to beef than to chicken and pork, due to lower feed conversion ratios and reproduction rates in beef production system and due to methane emissions from enteric fermentation (Nijdam et al., 2012, Westhoek et al., 2011). The results thus show that carbon footprints cannot generally be used as proxies for environmental impacts, as is sometimes suggested; in particular, they cannot be used as proxies for ecotoxicity impacts. This finding is in line with findings from other studies. Laurent et al. (2012) found that ecotoxicity impacts are not well-correlated with carbon footprints, based on a review of LCA-studies of over 4000 products from various sectors, and Röös et al. (2013) concluded, based on a review of LCA-studies of meat products, that carbon footprints generally cannot be used as indicators of toxicity across livestock species, and that toxicity impacts may be lower in grass-based production systems (e.g., cattle), than in grain-based production systems (e.g., chicken and pigs).

\subsection{Explanatory factors}

Three main factors explain the observed differences among the food products: 1) differences in conversion efficiencies in the assessed production systems, 2) differences in feed rations in the animal-based food production systems, and 3) differences in pesticide use and emissions (influenced by local pedoclimatic conditions) in the primary production of the assessed food products.

\subsubsection{Conversion efficiencies}

The plant-based food products have considerably smaller impact potentials than the animal-based food products since animal-based food production systems are less efficient at converting inputs (feed crops) to outputs (meat, milk, or eggs), due to losses of energy and nutrients associated with an additional trophic level in the food chain. Lower conversion efficiencies in animal-based food production systems thus magnify the ecotoxicity impacts associated with pesticide use in feed production, and the total use of pesticides per unit product becomes higher in animal-based food production systems than in plant-based food production systems.

Losses of energy and nutrients in animal-based food production systems are explained by multiple factors: 1 ) energy is required for body function maintenance and reproduction, 2) animals are unable to utilize all energy and nutrients in the feed, and 3) only a limited part of the animal body is fit for human consumption (Westhoek et al., 2011). In general, only between 10 and 30\% of the feed consumed by animals is converted to edible products (Westhoek et al., 2011). In the production

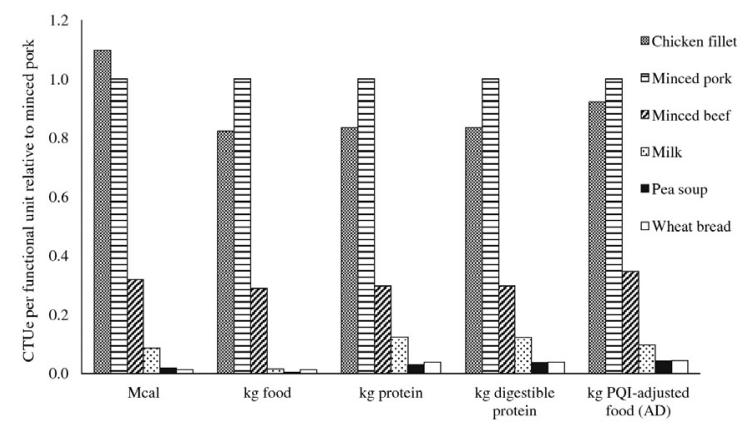

Fig. 4. Potential freshwater ecotoxicity impacts of food products in CTUe (Comparative Toxic Units ecotoxicity) per functional unit, relative to minced pork. PQI = protein quality index, $\mathrm{AD}=$ average Swedish diet.

\section{Table 4}

Carbon footprints and land use of animal- and plant-based food products based on a review of LCA-studies by Nijdam et al. (2012).

\begin{tabular}{|c|c|c|c|c|}
\hline \multirow[t]{2}{*}{ Food product } & \multicolumn{2}{|c|}{ Carbon footprints } & \multicolumn{2}{|l|}{ Land use } \\
\hline & $\begin{array}{l}\mathrm{kg} \mathrm{CO}_{2} \\
\mathrm{eq} / \mathrm{kg} \\
\text { protein }\end{array}$ & $\begin{array}{l}\mathrm{kg} \mathrm{CO} \\
\mathrm{eq} / \mathrm{kg} \text { food }\end{array}$ & $\begin{array}{l}\mathrm{m}^{2} \text { year } / \mathrm{kg} \\
\text { protein }\end{array}$ & $\begin{array}{l}\mathrm{m}^{2} \\
\text { year } / \mathrm{kg} \\
\text { food }\end{array}$ \\
\hline Beef (15 studies, $\mathrm{n}=26$ ) & $45-640$ & $9-129$ & $37-2100$ & $7-420$ \\
\hline Pork ( 8 studies, $\mathrm{n}=11$ ) & $20-55$ & $4-11$ & $40-75$ & $8-15$ \\
\hline Poultry ( 4 studies, $\mathrm{n}=5$ ) & $10-30$ & $2-6$ & $23-40$ & $5-8$ \\
\hline Milk ( 12 studies, $\mathrm{n}=14$ ) & $28-43$ & $1-2$ & $26-54$ & $1-2$ \\
\hline $\begin{array}{l}\text { Meat substitutes, } 100 \% \\
\quad \text { vegetal ( } 1 \text { study, } n=4)\end{array}$ & $6-17$ & $1-2$ & $4-25$ & $2-3$ \\
\hline Pulses, dry ( 2 studies, $\mathrm{n}=3$ ) & $4-10$ & $1-2$ & $10-43$ & $3-8$ \\
\hline
\end{tabular}

systems considered here, the ratios between live weight and bone-free meat are $0.36,0.44$ and 0.58 for beef, pork and chicken, respectively.

\subsubsection{Feed rations}

Chicken fillet and minced pork score higher than minced beef and milk, despite the fact that poultry and pigs have higher feed conversion ratios, and shorter cycle lengths, than cattle. This finding is explained by different feed rations of pigs, cattle, and poultry (Table 3), and the associated use of pesticides in the production of feed crops (see further Section 3.4.3).

The overall productivity of animal-based food production systems increases with shorter cycle lengths and higher fecundity and feed conversion ratios, generally in the order beef $<$ pork < poultry (Garnett et al., 2015, Westhoek et al., 2011, Nijdam et al., 2012). In the production systems considered here, ca. 12, 8, 4, and $1 \mathrm{~kg}$ feed (dry matter) are required to support the consumption of $1 \mathrm{~kg}$ minced beef, minced pork, chicken fillet, and milk in the household, respectively (Table 3).

In Västra Götaland, 36\% of the beef comes from specialized beef cattle and $64 \%$ comes from the dairy production system. Both beef and dairy cattle feed on considerable amounts of grass/clover (Table 3), with small impact potentials per kg harvested crop (Fig. 2). In contrast, chickens and pigs feed on considerable amounts of soymeal from soybeans, with large impact potentials per kg harvested crop (Fig. 2).

\subsubsection{Pesticide use in primary production}

Soybeans have the highest impact potential of all crops (Fig. 2). Our data show that soybean cultivation in Brazil involves a large number of pesticides applied frequently (see Table S2.8, Chapter S2 in the Supporting Information); significantly more than in any of the crops cultivated in Sweden. Seven out of the ten active substances with the highest impact scores (CTUe per kg harvested crop) are used in soybean cultivation in Brazil (see Chapter S14 in the Supporting Information). The pesticides that contribute most to the large impact potential of soybeans are two insecticides (lambda cyhalothrin and methomyl), and one fungicide (epoxiconazole, applied twice). Together, the two insecticides are responsible for $71 \%$ of the total impact score for soybeans, see Chapter S13 in the Supporting Information. Lambda cyhalothrin is a pyrethroid insecticide with "very high toxicity to aquatic life with long lasting effects," according to the EU Pesticides Database (EC, 2016a). Methomyl is associated with a high impact potential primarily due to a relatively large share $(4 \%)$ of the applied dose being emitted to air. In fact, this substance has the highest emission fraction to air of all substances included in this study.

Among the pesticides used in Sweden, lambda cyhalothrin and metazachlor have the largest impact potentials (see Chapter S14 in the Supporting Information). Lambda cyhalothrin, an insecticide, is used on average once every fifth year in barley and oats, against aphids. Metazachlor is a herbicide used every year in rapeseed against a wide range of grass- and broad-leaved weeds. Grass/clover has a small impact potential due to infrequent and low use of only two, relatively non- 
toxic, herbicides: glyphosate and amidosulfuron (see Chapter S8 in the Supporting Information for characterization factors).

The results show that oats and barley have 4 and 5 times larger impact potentials, respectively, than bread wheat (Fig. 2), despite being subject to less pesticides (Fig. 1). This somewhat surprising result is due to the use of lambda cyhalothrin in oats and barley. Wheat (for bread and feed) is also treated with a pyrethroid insecticide (on average once every third year), but this active substance, tau fluvalinate, causes a considerably smaller potential impact than lambda cyhalothrin. Differences in pesticide use in the studied crops and regions are discussed further in Section 4.

The results also show that emissions to air as a fraction of the applied dose on average are twice as high in Brazil, compared to Sweden. This is potentially because temperatures are higher in Brazil during the application months (see Table S5.2, Chapter S5 in the Supporting Information), which increases the volatilization potential of pesticides, see e.g., Burt (1974). Also, there is significantly more rainfall and more frequent rain events in Brazil than in Sweden, during application months (see Table S5.2, Chapter S5 in the Supporting Information), resulting in higher emissions to surface water as a fraction of the applied dose.

\section{Discussion}

\subsection{Pesticide use}

The results show that the crops produced in Sweden have much smaller potential freshwater ecotoxicity impacts compared to soybeans, produced in Brazil. Several interacting factors determine which pesticides, and how much, are used in crop production: cropping system, national legislation, pressure from weeds, pests and diseases, climate, weather, year (some pests are cyclical), and commodity prices. For example, Bayramoglu and Chakir (2016) showed that higher prices correlate positively with a higher demand for agro-chemical inputs such as pesticides. Here, the roles of cropping system and legislation are discussed, focusing on the situations in Brazil and Sweden.

\subsubsection{Cropping systems}

Cropping systems in Brazil are characterized by large-scale intensively managed mono-cropping systems in a tropical climate and widespread use of genetically engineered crops (Meyer and Cederberg, 2013). The pressure from pests and diseases is also substantial in Brazil since natural ecosystems in tropical climates naturally harbor a wide range of insects and fungi that can potentially harm crops (López et al., 2012) and since mono-cropping systems favor the development of pests and diseases, due to lack of natural predators and since insects and fungal diseases can easily spread over large areas. Due to increasing pressure from fungal diseases and insect pests in soybean production in Brazil, the use of fungicides and insecticides (measured as kg active substance per hectare) both increased by approximately 70\% between 2004 and 2008 (Meyer and Cederberg, 2010). In contrast, cropping systems in Sweden are less intensive, more diversified, and typically integrated in mixed landscapes with forests, permanent pastures, and arable lands with a mix between crop and grass production. Such cropping systems, in combination with a temperate climate, explains the lesser pressure from pests and diseases.

Genetically engineered soybeans, in particular glyphosate tolerant varieties, are widely used in Brazil (Meyer and Cederberg, 2013, López et al., 2012). In 2015, $94 \%$ of the Brazilian soybean acreage was cultivated with genetically engineered soybeans (SoyStats, 2016). According to López et al. (2012), an agricultural model based on genetic engineering of crops, heavily reliant on specific pesticides, is now applied throughout South America (mainly in Argentina, Brazil, Bolivia, Paraguay and Uruguay) "without critical evaluation, rigorous regulation and adequate information about the impact of sublethal doses on human health and the environment." The technology that makes crops tolerate glyphosate has been called the "most rapidly adopted technology in the history of agriculture" (Green, 2012), and has changed agricultural practices fundamentally. Some studies claim that the technology can reduce pesticide use (Uzogara, 2000, Phipps and Park, 2002). While that might be true in some cases, e.g., herbicide tolerant canola in Canada (Brimner et al., 2005), it is not always the case. In Brazil, herbicide use increased by $50 \%$ between 2003 and 2008 , in parallel with the large-scale adoption of genetically engineered glyphosate tolerant soybean (Meyer and Cederberg, 2010). In the case of maize and cotton in the US, Benbrook (2012) estimated that genetic engineering of crops to resist insect pests reduced insecticide use between 1996 and 2011, while with respect to herbicide tolerant crops (soybean, cotton, and maize), herbicide use, in particular glyphosate, increased, resulting in a net total increase in pesticide use by $7 \%$.

The use of glyphosate tolerant crops is also associated with an increasing number of glyphosate resistant weeds (Mortensen et al., 2012, Gilbert, 2013). Although genetic engineering of crops to tolerate glyphosate is not per se responsible for the development of pesticide resistance, the management practices associated with the cultivation of such crops favor the development, since weeds often are managed using glyphosate alone (Green, 2012, Owen and Hartzler, 2013). The International Survey of Herbicide Resistant Weeds (Heap, 2016) has so far (July 2016) documented resistance against EPSP synthase inhibitors (the herbicide group to which glyphosate belongs) in nine weed species in Brazil.

\subsubsection{Pesticide legislation}

Handford et al. (2015) reviewed global pesticide legislation and found that it varies greatly among countries and regions. Generally, legislation is stricter in developed countries, while developing countries often lack the resources and expertise to implement and/or enforce legislation. In particular, the EU is renowned for having one of the strictest pesticide legislations in the world (Handford et al., 2015). In a major reevaluation between 1998 and 2009 of all active substances allowed for use in the EU, three quarters of substances previously approved for use were banned (SLU, 2016). To regulate pesticides, most countries use maximum residue limits (MRLs), defined as "the highest level of a pesticide residue that is legally tolerated in or on food or feed when pesticides are applied correctly" (EC, 2016b). In some cases, MRLs vary enormously among countries (Handford et al., 2015). A comparison between MRLs in the EU, the US, Canada, China, Japan, India, Australia, and South Africa showed that MRLs generally are lowest in the EU (indicating the strictest legislation) and highest in the US (Handford et al., 2015).

In contrast to the situation in the EU, developing countries often lack adequate legislation in order to effectively regulate the use, labeling, storage, transport, and disposal of pesticides, due to limited awareness of the associated risks, and limited resources and expertise to develop and enforce legislation (Handford et al., 2015). In Brazil, pesticide legislation is a shared responsibility between three agencies: the Ministry of Agriculture, which evaluates and registers products; the Ministry of Health, which assesses human health risks, and the Ministry of Environment, which assesses environmental risks (Handford et al., 2015). However, the effectiveness of the existing legislation in providing adequate protection for human health and the environment has been questioned, both by researchers and journalists, see, e.g., Waichman et al. (2007), Pedlowski et al. (2012), and Prada (2015). Meanwhile, Brazil is the largest consumer of pesticides in the world (Pelaez et al., 2013, Meyer and Cederberg, 2013).

According to Waichman et al. (2007), some remote areas in Brazil almost completely lack law enforcement, and many farmers use pesticides carelessly and inappropriately, partly since they do not understand the information displayed on product labels. Limited risk awareness and careless use can result in exposure beyond safety thresholds. In one state alone (Mato Grosso do Sul), 1355 cases of pesticide poisoning were reported between 1992 and 2002 (Recena et al., 2006). 
Concerns have also been raised about the ability of Brazilian pesticide monitoring programs to fulfill their tasks. Barbosa et al. (2015) found significant weaknesses in the Brazilian Drinking Water Quality Surveillance Program, which monitors the presence of a selection of pesticides in drinking water: less than a fifth of the municipalities registered data; too few samples were generally taken and analyzed; sufficient information about detection and quantification limits was not available; and there were several inconsistencies in the gathering and presentation of data. Based on this, Barbosa et al. (2015) concluded that the data gathered within the program were impossible to use to evaluate the risks to the Brazilian population as a result of pesticide exposure via drinking water. This also indicates that there are significant limitations in our knowledge about the environmental impacts of pesticides in Brazil. Most studies on the environmental impacts of pesticides in Brazil that we have found, concern specific active substances, species, and regions, see, e.g., Souza et al. (2008), while comprehensive assessments seem to be lacking.

In order to support more sustainable soybean production, voluntary certification schemes, such as Round Table for Responsible Soy and ProTerra, have emerged in Brazil in recent years (Meyer and Cederberg, 2013). These involve stricter rules concerning pesticide use than the national legislation. For example, both schemes prohibit the use of pesticides listed in the Stockholm and Rotterdam conventions, and ProTerra also prohibits the use of pesticides listed in the WHO classes $1 \mathrm{a}$ and $\mathrm{b}$, and in the "Dirty Dozen" list of the Pesticide Action Network (Meyer and Cederberg, 2013). The development of voluntary certification schemes indicates that the national legislation is unable to satisfy market demands on sustainability. However, these certification schemes only have small market shares, hence presently little possibility to fundamentally influence production practices.

Pelaez et al. (2013) compared pesticide regulations in Brazil, the EU, and the US and found interesting and noteworthy differences. In the EU and the US, pesticides are approved for limited time periods (10 and 15 years, respectively), and manufacturers are responsible for demonstrating that pesticides do not cause unacceptable risks to human health or the environment. In contrast, pesticides registered for use in Brazil have no expiry date. Pesticides can however be subject for re-evaluation, in which case the regulatory agency is responsible for demonstrating unacceptable risks to human health or the environment (Pelaez et al., 2013). Another striking difference is the number of people working with pesticide legislation in the US and Brazil, respectively (no information available for the EU): 850 persons at the Office of Pesticide Management in the US, compared to 46 persons in Brazil, distributed among three agencies (Pelaez et al., 2013). This is remarkable considering that Brazil is the largest consumer of pesticides in the world, followed by the US. This also indicates that Brazilian pesticide law enforcement likely suffers from a lack of both financial and human resources.

\subsection{How can ecotoxicity impacts in food production be reduced?}

Given the importance of addressing chemical pollution worldwide, it is imperative to take actions toward reducing ecotoxicity impacts in food production. In the following, four main strategies are described and discussed.

\subsubsection{Changing feed rations in animal-based food production systems}

Impact scores vary greatly among crops, by up to 3 orders of magnitude (Fig. 2). Hence, impacts in animal-based food production systems can be reduced by changing feed rations. In particular, soybeans dominate the impact potentials of chicken and pork (Fig. 3); these could potentially be replaced by other protein-rich feed crops, such as field peas, faba beans, or lupins. In a complementary calculation, we assessed the potential freshwater ecotoxicity impact of broad beans cultivated in Västra Götaland, Sweden, see Chapter S15 in the Supporting Information. The results show that the impact potential of broad beans is similar to grass/clover (5.2E - 05 CTUe per kg harvested crop for broad beans, compared to 9.4E - 06 CTUe per kg harvested crop for grass/clover). Peas also have relatively small impact potentials $(2.3 \mathrm{E}-04$ CTUe per $\mathrm{kg}$ harvested crop, see Fig. 2). There are also ongoing efforts to develop soybean varieties suitable for cultivation in Europe, see e.g., the DanubeSoya initiative (http://www.donausoja.org). If such breeding programs are successful, they may offer a future local source of soybeans with lower ecotoxicity impacts than soybeans imported from South America.

In order to qualitatively assess the mitigation potentials associated with changes in feed rations, we developed two alternative, locally sourced and soy-free feed rations for chickens and pigs, and assessed their potential freshwater ecotoxicity impacts. The results show that the impact potentials of chicken fillet and minced pork were reduced by 91 and 70\%, respectively, when the alternative feed rations were used, compared to the reference feed rations. The soy-free feed rations and the results of this calculation are presented in Chapter S16 in the Supporting Information.

The European livestock sector is highly dependent on imported protein-rich feed crops: approximately 75\% comes from South America, primarily Brazil and Argentina, and consists mainly of soybeans (Westhoek et al., 2011). The amino-acid composition of soymeal makes it ideal as livestock feed, but soybeans are also associated with several negative externalities, primarily environmental impacts associated with deforestation, such as loss of biodiversity and carbon stocks and socio-economic impacts associated with displacement of small-holders and heavy reliance on patented, often genetically engineered, seeds from a few multinational corporations (Westhoek et al., 2011, Meyer and Cederberg, 2013). Therefore, besides contributing to lower ecotoxicity impacts, replacing soybeans with locally produced protein-rich feed crops could also potentially have other benefits: higher self-sufficiency rate and improved food security in the EU as well as decreased pressure on land in South America (although re-bound effects associated with indirect land use changes may partly counteract these benefits).

\subsubsection{Diversifying pest management}

In most crops, only a single or a few active substances dominate the impact potentials. Hence, impacts can be significantly reduced by avoiding one or a few of the most ecotoxic pesticides, or by replacing them with less harmful substitutes. Nordborg et al. (2014) showed that the impact potential of rapeseed could be reduced by $85 \%$ by replacing the most ecotoxic insecticide with an equivalent dose of a less ecotoxic insecticide.

Integrated Pest Management is a set of management tools that can contribute to reducing the use of pesticides, and the associated risks to human health and the environment, by utilizing a wide range of pest control techniques (mechanical, biological and chemical), including preventive measures (FAO, 2016). Examples of Integrated Pest Management measures are 1) adapting the use of pesticides to the pressure from weeds, pests, and diseases through improved monitoring and information systems, 2) using varieties with natural resistance against pests and diseases, 3 ) reducing pesticide emissions through, e.g., improved handling of pesticides, use of technical equipment and buffer zones, and 4) using crop rotations that reduce the need for pesticides. Sonesson et al. (2016) showed that pesticide use in pork production in Sweden could be reduced by approximately $50 \%$, in relation to a reference scenario representing current practice, by implementing a combination of measures such as more mechanical weeding, advanced pest forecasts, more frequent ploughing, and improved crop rotations with more cover crops.

Various measures could potentially be used to achieve a more diversified pest management: legislative measures (e.g., restricting or banning certain pesticides), voluntary certification schemes, and awareness raising. For example, experience from Sweden shows that by providing information to farmers on how to handle pesticides and spray equipment in order to reduce emissions, pesticide concentrations in nearby streams were reduced by $>90 \%$ (Kreuger and Nilsson, 2001). 


\subsubsection{Changing diets}

We found that the plant-based food products have considerably smaller impact potentials than the animal-based food products. Although only two plant-based food products were considered here, this finding is likely to be generalizable across a wider range of food products based on cereals and/or legumes that are subject to similar pesticide applications. Thus, diet-related ecotoxicity impacts could be reduced by substituting animal-based food products with plant-based food products, i.e., by eating more vegetarian/vegan food and less meat.

Shifting from a diet based on animal protein to a diet based on vegetable protein would also reduce the diet-related climate impacts and land use, as shown by several studies (Bryngelsson et al., 2016, Hallström et al., 2015, Hedenus et al., 2014). A review of nearly 50 diets found that a vegan diet can reduce climate impacts and land use by up to $50 \%$, compared to a reference diet representing current consumption (Hallström et al., 2015). Also, for Sweden, reduced consumption of animal-based proteins could significantly lower the emissions of nitrogen and phosphorous to the Baltic sea (Vallin et al., 2016).

Shifting toward more plant-based diets would also be beneficial from a public-health perspective, given that meat consumption currently exceeds health-based dietary recommendations in many countries. For example, the consumption of red meat in the EU is twice as high as recommended from a public-health perspective (Westhoek et al., 2011). A strong body of scientific evidence links over-consumption of meat, in particular red meat and processed meat, to a number of diseases such as diabetes, coronary heart disease, and certain types of cancer (Micha et al., 2012, Chan et al., 2011).

Despite major synergies between healthy and sustainable diets (Tilman and Clark, 2014), dietary guidelines are generally only based on nutritional considerations. Gonzalez Fischer and Garnett (2016) reviewed dietary guidelines world-wide, and only found four countries in which dietary guidelines considered sustainability issues associated with food production: Brazil, Germany, Sweden, and Qatar. These guidelines all recommend high intake of fresh fruits and vegetables, with limited intake of meat, in particular red and processed meat, and stress that a largely plant-based diet is preferred, both from a health and environmental perspective.

Our results also show that beef scores considerably lower than chicken and pork (Fig. 4), suggesting that substituting beef for chicken and pork could reduce the diet-related ecotoxicity impacts. Such dietshifts would however be negative with regard to climate impacts, land use, and public health. Lastly, it should be noted that although dietshifts toward more plant-based diets would likely be associated with many positive effects, it is very hard to predict all direct and indirect effects associated with large-scale diet shifts. Vegetarian diets may, e.g. contain more "exotic" fruits and vegetables that may be associated with high ecotoxicity impacts.

\subsubsection{Increasing productivity and reducing waste through the supply chain}

By making production systems more efficient and reducing waste and losses through the supply chain, food-related ecotoxicity impacts could be reduced, since less food would need to be produced. First, by closing or decreasing yield gaps in crop production, impacts associated with both plant- and animal-based food products could be reduced. Historically, yield increases have been achieved partly through increased use of pesticides (Bringezu et al., 2014), but in recent decades, yield increases have slowed down (Wirsenius et al., 2010, Bringezu et al., 2014). It is unlikely that major yield increases could be achieved without simultaneously increasing pesticide use, unless significant advances in crop genetics are made. Genetic engineering of crops to resist insect pests and fungal diseases could potentially increase yields without increasing ecotoxicity impacts (see Section 4.1). However, insects tend to develop resistance, also against crops genetically engineered to produce their own insecticides, see, e.g., Gassmann et al. (2014). Therefore, yield increases are not expected to offer significant reductions in foodrelated ecotoxicity impacts.
Second, shorter cycle lengths and higher feed conversion ratios that make animals grow faster could reduce ecotoxicity impacts in livestock production systems (Bryngelsson et al., 2016). Given that livestock production systems already are highly efficient in most parts of the developed world, the largest improvement potentials are found in developing countries. However, increases in animal productivity could be negative from an animal-welfare perspective, especially in production systems that are already highly productive. At the same time, it can be argued that improved animal health and welfare is a prerequisite for high production performance, but it incurs extra costs.

Thirds, impacts could be reduced by reducing losses and waste through the supply chain, from primary production to end consumer. For example, Eberle and Fels (2014) estimated that, in Germany, between 14 and $20 \%$ of the environmental impacts of food consumption, depending on impact category, are attributed to food losses along the supply chain. Technical solutions, behavioral changes (e.g., concerning which animal parts are considered edible), and legislation could reduce food waste. An example is the French law from February 2016, which prohibits supermarkets from throwing away food (Sénat, 2016).

\subsection{Uncertainties}

Despite a detailed and site-specific inventory of pesticide use and emissions in the studied crops and regions, the results should be interpreted with caution due to several uncertainties. Some data used in the modeling display large spatial and/or temporal variability, e.g., the choice of pesticide products, pesticide application rates, pedoclimatic parameters used in emission modeling, and feed rations.

While pork and poultry production systems are highly standardized across the developed world, beef production systems display large variability, from extensive, mainly grass-based, production systems, to intensive feedlot production systems heavily dependent on concentrated, protein-rich feedstuff (Westhoek et al., 2011). We considered beef production in Västra Götaland, Sweden, in which $36 \%$ of the beef comes from specialized beef cattle, and $64 \%$ comes from the dairy system (surplus calves and culled cows). The corresponding numbers for the EU are 40 and 60\%, respectively (Westhoek et al., 2011). However, in addition to grass, cereals, and protein-rich feed crops, European beef production systems also use considerable amounts of maizebased feedstuff (Westhoek et al., 2011), not included in the feed rations assessed here (see Table 3). Therefore, the results should not be extrapolated beyond the production systems considered here, especially when it comes to beef.

The LCA methodology is associated with several limitations and uncertainties. Although the methodology has been standardized by the International Organization for Standardization, cross-study comparisons are not always possible due to methodological differences in terms of, e.g., system boundaries, allocation methods and impact assessment models. Also, it should be noted that LCA aims to quantify potential environmental impacts, rather than actual effects, in line with the comparative, rather than predictive, context in which LCA is typically applied.

USEtox ecotoxicity characterization factors have an estimated uncertainty range of 1-2 orders of magnitude (Rosenbaum et al., 2008). The most uncertain input parameters are substances' half-lives in different environmental media, and ecotoxicological effect factors (Henderson et al., 2011). The uncertainties associated with pesticide emissions have not been quantified (Dijkman et al., 2012). Hence, the uncertainty range of impact scores (which depend on both emissions and characterization factors) could not be quantified.

There is no scientifically objective way to measure the ecotoxicity impacts of chemicals. Therefore, many (eco)toxicity impact assessment models have been developed over the years that differ in scope, modeling principles, number of substances and compartments included, and in terms of substance ranking (Hauschild et al., 2011). Examples of models that build on the modeling of fate, exposure and effect include EDIP (Hauschild et al., 1998), CML2001 (Guinée, 2001), Eco-indicator 
99 (Goedkoop and Spriensma, 2001), USES-LCA (Huijbregts et al., 2000, Van Zelm et al., 2009), IMPACT 2002 + (Jolliet et al., 2003), and ReCiPe (Goedkoop et al., 2009). Simpler approaches also exist, such as the Critical Dilution Volume method, see, e.g., Van Hoof et al. (2011).

When it comes to the modeling of pesticide emissions, several transport models are available that model the run-off and/or the transportation of pesticide in soil, but most of them are not developed for use in LCA (Arias-Estévez et al., 2008). One example is MACRO v. 5.2 (Jarvis and Larsbo, 2012), widely used in regulatory risk assessment of pesticides in the EU. To our knowledge, PestLCI is the only pesticide distribution model that has been developed specifically for use in LCA.

In summary, the modeling upon which these results are based is inherently complex and subject to many assumptions and simplifications. Therefore, and since impact scores represent potential impacts rather than actual effects, the results cannot be validated against experimental data. However, results can partly be compared with results from other studies. For example, we found that the pesticides with largest emissions to surface water are glyphosate, quinmerac, metazachlor, tribenuron methyl, amidosulfuron, and bentazone (see Chapter S17 in the Supporting Information). These findings can be compared with results from the Swedish National Monitoring Program of pesticides in the environment, showing that these active substances indeed have a high tendency to end up in aquatic freshwater ecosystems: glyphosate, quinmerac, metazachlor, tribenuron methyl, amidosulfuron, and bentazone were detected in (approximately) 90, 55, 65, 13, 15, and $100 \%$ of water samples from streams and river in the latest sampling period (Lindström et al., 2015).

\section{Conclusions and recommendations}

We assessed the potential freshwater ecotoxicity impacts from pesticide use in the primary production of six food products of animal and vegetable origin (chicken fillet, minced pork, minced beef, milk, pea soup and bread), based on a detailed and site-specific inventory of pesticide use and emissions in the studied crops and regions. Since the choice of functional unit can have a large influence on results and conclusions, impacts were assessed in relation to five different functional units.

The animal-based food products have considerably larger potential freshwater ecotoxicity impacts than the plant-based food products, due to lower conversion efficiencies in animal-based food production systems. The choice of functional unit does not change this conclusion. All mass-based functional units yield the same ranking of the food products: impact potentials decrease in the order minced pork > chicken fillet $>$ minced beef $>$ milk $>$ bread $>$ pea soup. In relation to $\mathrm{kg}$ pea soup, impact potentials of bread, milk, minced beef, chicken fillet and minced pork are ca. 2, 3, 50, 140 and 170 times larger, respectively.

Notably, chicken fillet and minced pork score higher than minced beef and milk, regardless of functional unit. This result stands in sharp contrast to typical carbon footprint and land-use results, which attribute larger impacts to beef, than to chicken and pork. This finding shows that carbon footprints cannot be used as proxies of ecotoxicity impacts of food products, and points to the importance of considering a wide range of impact categories (beyond carbon footprints) in environmental assessments of food products.

Given the importance of addressing chemical pollution worldwide, it is imperative actions toward reducing ecotoxicity impacts in food production systems are taken. Pesticides used in soybean production dominate the impact potentials of chicken fillet and minced pork. By substituting soybeans with locally sourced, protein-rich feed crops, the impact potentials of chicken fillet and minced pork decrease by ca. 90 and $70 \%$, respectively. Such changes in feed rations would also have other benefits: higher self-sufficiency rate and improved food security in the EU, and lower pressure on land in South America where soybean production is associated with several negative externalities.
Ecotoxicity impacts can also be reduced by substituting animalbased food products with plant-based food products; increasing efficiencies in food production systems; reducing food waste along the supply-chain, and by applying Integrated Pest Management measures to pesticide use. In the EU Directive on the Sustainable Use of Pesticides (2009/128/EC), which came into force in 2009, Integrated Pest Management is mandatory. Adoption and enforcement of this directive is one step forward toward reducing ecotoxicity impacts associated with food production in the EU, but stricter legislation and more resources to enforce legislation are needed in other parts of the world.

Soybean production in Brazil involves considerably more pesticides than the crop production in Sweden. We propose that weak legislation, in combination with tropical climate and agronomic practices (largescale intensively managed monocultures and widespread use of glyphosate tolerant soybean varieties), explain this situation. The EU has among the strictest pesticide legislations in the world, while the pesticide legislation in Brazil suffers from weaknesses both in terms of content and enforcement. The development of voluntary certification schemes in Brazil indicates that the national legislation is unable to satisfy market demands on sustainability. More research is needed in order to investigate the links between legislation, pesticide use, and the associated environmental impacts in Brazil. To enable such research, more transparency in the agro-business, and high-quality data on pesticide use in different crops and regions, is needed.

Only a limited number of food products were assessed here. More research is needed in order to assess the impacts of a wider range of food products produced in different regions and under different conditions, e.g., beef from intensive feedlot production systems and tropical fruits. Bananas and pineapples, for example, are highly pesticide intensive, with approximately 45 and $30 \mathrm{~kg}$ active substance per hectare and year, respectively, according to a study from Costa Rica (Diepens et al., 2014).

This study is subject to a number of limitations: we did not consider emissions to agricultural soils and ground water; drainage systems; marine and terrestrial ecotoxicity (e.g., ecotoxicity to pollinators); pesticide degradation products; non-active pesticide product ingredients (e.g., solvents and surfactants); mixture toxicity effects; or ecotoxicity associated with other substances used in food production such as antibiotics in animal rearing. More comprehensive assessments are needed in order to address these limitations, which are further discussed in Chapter S18 in the Supporting Information. More comprehensive assessments of food products also need to consider other environmental impact categories as well as, e.g., social impacts associated with production, food-security, and animal-welfare issues.

\section{Acknowledgements}

The authors wish to thank Teunis J. Dijkman, Technical University of Denmark, and Ulf Sonesson, SP Technical Research Institute of Sweden, for modeling support and Paulina Essunger for proof reading. This work was supported by funding from Vinnova (the Swedish Innovation Agency) (2011-03764), the Federation of Swedish Farmers (LRF), the Swedish Food Federation, the Swedish Retail Federation, and Västra Götaland Region (FE014). The financial support is gratefully acknowledged.

\section{Appendix A. Supporting information}

Supporting information to this article can be found online at http:// dx.doi.org/10.1016/j.scitotenv.2016.12.153.

\section{References}

Aiking, H., 2014. Protein production: planet, profit, plus people? Am. J. Clin. Nutr. 100 483-489.

Arias-Estévez, M., López-Periago, E., Martínez-Carballo, E., Simal-Gándara, J., Mejuto, J.C. García-Río, L., 2008. The mobility and degradation of pesticides in soils and the pollution of groundwater resources. Agric. Ecosyst. Environ. 123 (4), 247-260. 
Barbosa, A.M.C., Solano, M.D.L.M., Umbuzeiro, G.D.A., 2015. Pesticides in drinking water the Brazilian monitoring program. Front. Publ. Health 3, 246.

Bayramoglu, B., Chakir, R., 2016. The impact of high crop prices on the use of agro-chemical inputs in France: a structural econometric analysis. Land Use Policy 55, 204-211.

Beketov, M.A., Kefford, B.J., Schäfer, R.B., Liess, M., 2013. Pesticides reduce regional biodiversity of stream invertebrates. Proc. Natl. Acad. Sci. 110, 11039-11043.

Benbrook, C.M., 2012. Impacts of genetically engineered crops on pesticide use in the USthe first sixteen years. Environ. Sci. Eur. 24 (1)

Brimner, T.A., Gallivan, G.J., Stephenson, G.R., 2005. Influence of herbicide-resistant canola on the environmental impact of weed management. Pest Manag. Sci. 61, 47-52.

Bringezu, S., Schütz, H., Pengue, W., O'Brien, M., Garcia, F., Sims, R., Howarth, R.W., Kauppi, L., Swilling, M., Herrick, J., 2014. Assessing Global Land Use: Balancing Consumption With Sustainable Supply. Nairobi, United Nations Environment Programme (131 pp).

Bryngelsson, D., Wirsenius, S., Hedenus, F., Sonesson, U., 2016. How can the EU climate targets be met? A combined analysis of technological and demand-side changes in food and agriculture. Food Policy 59, 152-164.

Burt, G.W., 1974. Volatility of atrazine from plant, soil, and glass surfaces. J. Environ. Qual. 3, 114-117.

Chan, D.S., Lau, R., Aune, D., Vieira, R., Greenwood, D.C., Kampman, E., Norat, T., 2011. Red and processed meat and colorectal cancer incidence: meta-analysis of prospective studies. PLoS One 6, e20456.

De Vries, M., De Boer, I.J.M., 2010. Comparing environmental impacts for livestock products: a review of life cycle assessments. Livest. Sci. 128, 1-11.

Diamond, M.L., De Wit, C.A., Molander, S., Scheringer, M., Backhaus, T., Lohmann, R., Arvidsson, R., Bergman, A., Hauschild, M., Holoubek, I., Persson, L., Suzuki, N., Vighi, M., Zetzsch, C., 2015. Exploring the planetary boundary for chemical pollution. Environ. Int. 78, 8-15

Diepens, N.J., Pfennig, S., Van Den Brink, P.J., Gunnarsson, J.S., Ruepert, C., Castillo, L.E. 2014. Effect of pesticides used in banana and pineapple plantations on aquatic ecosystems in Costa Rica. J. Environ. Biol. 35, 73-84.

Dijkman, T.J., Birkved, M., Hauschild, M.Z., 2012. PestLCI 2.0: a second generation mode for estimating emissions of pesticides from arable land in LCA. Int. J. Life Cycle Assess. 17, 973-986.

Eberle, U., Fels, J., 2014. Environmental impacts of German food consumption and food losses. Int. J. Life Cycle Assess. 21, 759-772.

EC, 2016a. EU Pesticides Database [Online]. Available: http://ec.europa.eu/food/plant/ pesticides/eu-pesticides-database (Accessed August 4, 2016).

EC, 2016b. Maximum Residue Levels [Online]. European Commission. Available: http://ec europa.eu/food/plant/pesticides/max_residue_levels/index_en.htm (Accessed August 4, 2016).

Fantke, P.E., Huijbregts, M.A.J., Margni, M., Hauschild, M.Z., Jolliet, O., Mckone, T.E., Rosenbaum, R.K., van de Meent, D., 2015a. USEtox 2.0 User Manual. (Version 2), 30 pp, Available:. http://usetox.org.

Fantke, P., Huijbregts, M., Margni, M., van de Meent, D., Jolliet, O., Rosenbaum, R.K., Mckone, T.E., Hauschild, M., 2015b. USEtox 2.0 Manual: Organic Substances. (version 2), 18 pp, Available http://usetox.org.

FAO, 2016. AGP - Integrated Pest Management [Online]. The Food and Agriculture Organization of the United Nations Available:. http://www.fao.org/agriculture/crops/ thematic-sitemap/theme/pests/ipm/en/ (Accessed July 26, 2016).

Garnett, T., Röös, E., Little, D., 2015. Lean, Green, Mean, Obscene...? What Is Efficiency? And Is It Sustainable? University of Oxford, Food Climate Research Network (48 pp)

Gassmann, A.J., Petzold-Maxwell, J.L., Clifton, E.H., Dunbar, M.W., Hoffmann, A.M., Ingber, D.A., Keweshan, R.S., 2014. Field-evolved resistance by western corn rootworm to multiple Bacillus thuringiensis toxins in transgenic maize. Proc. Natl. Acad. Sci. 111, 5141-5146.

Geiger, F., Bengtsson, J., Berendse, F., Weisser, W.W., Emmerson, M., Morales, M.B. Ceryngier, P., Liira, J., Tscharntke, T., Winqvist, C., 2010. Persistent negative effects of pesticides on biodiversity and biological control potential on European farmland. Basic Appl. Ecol. 11, 97-105.

Gilbert, N., 2013. A hard look at GM crops. Nature 497, 24-26.

Goedkoop, M., Spriensma, R., 2001. The Eco-indicator 99. A Damage Oriented Method for Life Cycle Impact Assessment. Methodology Report. third ed. (Pré Consultants: Amersfoort).

Goedkoop, M., Heijungs, R., Huijbregts, M., De Schryver, A., Struijs, J., Van Zelm, R., 2009. ReCiPe 2008: A Life Cycle Impact Assessment Method Which Comprises Harmonised Category Indicators at the Midpoint and the Endpoint Level; First Edition; Report I: Characterisation. Dutch Ministry of Housing, Spatial Planning and Environment (VROM), The Hague.

Gonzalez Fischer, C., Garnett, T., 2016. Plates, Pyramids, Planet: Developments in National Healthy and Sustainable Dietary Guidelines: A State of Play Assessment. The Food and Agriculture Organization of the United Nations and the Food Climate Research Network at the University of Oxford ( $80 \mathrm{pp}$ ).

Green, J.M., 2012. The benefits of herbicide-resistant crops. Pest Manag. Sci. 68 1323-1331.

Guinée, J.B., 2001. Life cycle assessment: an operational guide to the ISO standards; LCA in perspective; operational annex to guide. Centre for Environmental Science. Leiden University, Leiden.

Hallmann, C.A., Foppen, R.P., van Turnhout, C.A., De Kroon, H., Jongejans, E., 2014. Declines in insectivorous birds are associated with high neonicotinoid concentrations. Nature $511,341-343$.

Hallström, E., Carlsson-Kanyama, A., Börjesson, P., 2015. Environmental impact of dietary change: a systematic review. J. Clean. Prod. 91, 1-11.

Handford, C.E., Elliott, C.T., Campbell, K., 2015. A review of the global pesticide legislation and the scale of challenge in reaching the global harmonization of food safety standards. Integr. Environ. Assess. Manag. 11, 525-536.
Hauschild, M.Z., Wenzel, H., Damborg, A., Tørsløv, J., Wenzel, H., 1998. Ecotoxicity as a criterion in the environmental assessment of products. In: Hauschild, M. (Ed.), Environmental Assessment of Products: Volume 2: Scientific Background. Chapman \& Hall, London, pp. 203-314.

Hauschild, M.Z., Huijbregts, M., Jolliet, O., Macleod, M., Margni, M., van De Meent, D., Rosenbaum, R.K., Mckone, T.E., 2008. Building a model based on scientific consensus for life cycle impact assessment of chemicals: the search for harmony and parsimony. Environ. Sci. Technol. 42, 7032-7037.

Hauschild, M.Z., Jolliet, O., Huijbregts, M.A.J., 2011. A bright future for addressing chemical emissions in life cycles assessment. Int. J. Life Cycle Assess. 16 (8), 697-700.

Hauschild, M.Z., Goedkoop, M., Guinee, J., Heijungs, R., Huijbregts, M., Jolliet, O., Margni, M., De Schryver, A., Humbert, S., Laurent, A., Sala, S., Pant, R., 2013. Identifying best existing practice for characterization modeling in life cycle impact assessment. Int. J. Life Cycle Assess. 18, 683-697.

Heap, I., 2016. The International Survey of Herbicide Resistant Weeds [Online]. Available: www.weedscience.org (Accessed July 25, 2016).

Hedenus, F., Wirsenius, S., Johansson, D.J.A., 2014. The importance of reduced meat and dairy consumption for meeting stringent climate change targets. Clim. Chang. 124, 79-91.

Henderson, A.D., Hauschild, M.Z., van De Meent, D., Huijbregts, M.A., Larsen, H.F., Margni, M., Mckone, T.E., Payet, J., Rosenbaum, R.K., Jolliet, O., 2011. USEtox fate and ecotoxicity factors for comparative assessment of toxic emissions in life cycle analysis: sensitivity to key chemical properties. Int. J. Life Cycle Assess. 16, 701-709.

Henriksson, P.J., Guinée, J.B., Kleijn, R., De Snoo, G.R., 2012. Life cycle assessment of aquaculture systems-a review of methodologies. Int. J. Life Cycle Assess. 17, 304-313.

Henry, M., Beguin, M., Requier, F., Rollin, O., Odoux, J.-F., Aupinel, P., Aptel, J., Tchamitchian, S., Decourtye, A., 2012. A common pesticide decreases foraging success and survival in honey bees. Science 336, 348-350.

Huijbregts, M.A.J., Thissen, U., Guinée, J.B., Jager, T., Kalf, D., van De Meent, D., Ragas, A.M.J., Wegener Sleeswijk, A., Reijnders, L., 2000. Priority assessment of toxic substances in life cycle assessment. Part I: calculation of toxicity potentials for 181 substances with the nested multi-media fate, exposure and effects model USES-LCA. Chemosphere 41 (4), 541-573.

Jarvis, N., Larsbo, M., 2012. MACRO (v5.2): model use, calibration, and validation. Trans. ASABE 55 (4), 1413-1423.

Jolliet, O., Margni, M., Charles, R., Humbert, S., Payet, J., Rebitzer, G., Rosenbaum, R., 2003. IMPACT $2002+$ : a new life cycle impact assessment methodology. Int. J. Life Cycle Assess. 8 (6), 324-330.

JRC, 2010. International Reference Life Cycle Data System (ILCD) Handbook - General Guide for Life Cycle Assessment - Detailed Guidance. European Commission Joint Research Centre - Institute for Environment and Sustainability, Luxembourg.

KEMI, 2014. Försålda kvantiteter av bekämpningsmedel, Sveriges officiella statistik 2013. Stockholm, Kemikalieinspektionen.

Kreuger, J., Nilsson, E., 2001. Catchment scale risk-mitigation experiences - key issues for reducing pesticide transport to surface waters. BCPC Symposium Proceedings NO. 78: Pesticide Behaviour in Soil and Water.

Laurent, A., Olsen, S.I., Hauschild, M.Z., 2012. Limitations of carbon footprint as indicator of environmental sustainability. Environ. Sci. Technol. 46, 4100-4108.

Lindström, B., Larsson, M., Boye, K., Gönczi, M., Kreuger, J., 2015. Resultat från miljöövervakningen av bekämpningsmedel (växtskyddsmedel). Långtidsöversikt och trender 2002-2012 för ytvatten och sediment. (In Swedish). The Swedish University of Agricultural Sciences, Report 2015, 5

López, S.L., Aiassa, D., Benitez-Leite, S., Lajmanovich, R., Manas, F., Poletta, G., Sánchez, N., Simoniello, M.F., Carrasco, A.E., 2012. Pesticides used in South American GMO-based agriculture: a review of their effects on humans and animal models. Adv. Mol. Toxicol. 6, 41-75.

Meyer, D., Cederberg, C., 2010. Pesticide Use and Glyphosate Resistant Weeds - A Case Study of Brazilian Soybean Production. The Swedish Institute for Food and Biotechnology (SIK), Gothenburg.

Meyer, D., Cederberg, C., 2013. Certification Schemes (RTRS and ProTerra) in Brazilian Soy: Use of Pesticides and Cropping Systems. SR 865. The Swedish Institute for Food and Biotechnology (SIK), Gothenburg.

Micha, R., Michas, G., Mozaffarian, D., 2012. Unprocessed red and processed meats and risk of coronary artery disease and type 2 diabetes-an updated review of the evidence. Curr. Atheroscler. Rep. 14, 515-524.

Mortensen, D.A., Egan, J.F., Maxwell, B.D., Ryan, M.R., Smith, R.G., 2012. Navigating a critical juncture for sustainable weed management. Bioscience 62, 75-84.

Nemecek, T., Jungbluth, N.I., Canals, L.M., Schenck, R., 2016. Environmental impacts of food consumption and nutrition: where are we and what is next? Int. J. Life Cycle Assess. 21, 607-620.

Nijdam, D., Rood, T., Westhoek, H., 2012. The price of protein: review of land use and carbon footprints from life cycle assessments of animal food products and their substitutes. Food Policy 37, 760-770.

Nordborg, M., Cederberg, C., Berndes, G., 2014. Modeling potential freshwater ecotoxicity impacts due to pesticide use in biofuel feedstock production: the cases of maize, rapeseed, Salix, soybean, sugar cane, and wheat. Environ. Sci. Technol. 48, 11379-11388.

Owen, M.D.K., Hartzler, R., 2013. 2014 Herbicide Guide for Iowa Corn and Soybean Production. Iowa State University Extension Weed Management, Ames.

Pedlowski, M.A., Canela, M.C., Da Costa Terra, M.A., Ramos de Faria, R.M., 2012. Modes of pesticides utilization by Brazilian smallholders and their implications for human health and the environment. Crop. Prot. 31, 113-118.

Pelaez, V., da Silva, L.R., Araújo, E.B., 2013. Regulation of pesticides: a comparative analysis. Sci. Public Policy 40, 644-656. 
Phipps, R., Park, J., 2002. Environmental benefits of genetically modified crops: global and European perspectives on their ability to reduce pesticide use. J. Anim. Feed Sci. 11, $1-18$.

Prada, P., 2015. Why Brazil Has a Big Appetite for Risky Pesticides [Online]. Reuters Available: http://www.reuters.com/investigates/special-report/brazil-pesticides/ (Accessed July 28, 2016).

Recena, M.C.P., Pires, D.X., Caldas, E.D., 2006. Acute poisoning with pesticides in the state of Mato Grosso do Sul, Brazil. Sci. Total Environ. 357, 88-95.

Rockström, J., Steffen, W., Noone, K., Persson, A., Chapin, F.S., Lambin, E., Lenton, T.M., Scheffer, M., Folke, C., Schellnhuber, H.J., Nykvist, B., De Wit, C.A., Hughes, T., van Der Leeuw, S., Rodhe, H., Sorlin, S., Snyder, P.K., Costanza, R., Svedin, U., Falkenmark, M., Karlberg, L., Corell, R.W., Fabry, V.J., Hansen, J., Walker, B., Liverman, D., Richardson, K., Crutzen, P., Foley, J., 2009. Planetary boundaries: exploring the safe operating space for humanity. Ecol. Soc. 14 (2), 32.

Röös, E., Sundberg, C., Tidåker, P., Strid, I., Hansson, P.A., 2013. Can carbon footprint serve as an indicator of the environmental impact of meat production? Ecol. Indic. 24, 573-581.

Rosenbaum, R.K., Bachmann, T.M., Gold, L.S., Huijbregts, M.A.J., Jolliet, O., Juraske, R., Koehler, A., Larsen, H.F., Macleod, M., Margni, M., Mckone, T.E., Payet, J., Schuhmacher, M., van De Meent, D., Hauschild, M.Z., 2008. USEtox-the UNEP-SETAC toxicity model: recommended characterisation factors for human toxicity and freshwater ecotoxicity in life cycle impact assessment. Int. J. Life Cycle Assess. 13, 532-546.

Rosenbaum, R., Anton, A., Bengoa, X., Bjørn, A., Brain, R., Bulle, C., Cosme, N., Dijkman, T., Fantke, P., Felix, M., Geoghegan, T., Gottesbüren, B., Hammer, C., Humbert, S., Jolliet, O., Juraske, R., Lewis, F., Maxime, D., Nemecek, T., Payet, J., Räsänen, K., Roux, P., Schau, E., Sourisseau, S., Van Zelm, R., von Streit, B., Wallman, M., 2015. The Glasgow consensus on the delineation between pesticide emission inventory and impact assessment for LCA. Int. J. Life Cycle Assess. 20, 765-776.

Roy, P., Nei, D., Orikasa, T., Xu, Q.Y., Okadome, H., Nakamura, N., Shiina, T., 2009. A review of life cycle assessment (LCA) on some food products. J. Food Eng. 90, 1-10.

Schäfer, R.B., Caquet, T., Siimes, K., Mueller, R., Lagadic, L., Liess, M., 2007. Effects of pesticides on community structure and ecosystem functions in agricultural streams of three biogeographical regions in Europe. Sci. Total Environ. 382, 272-285.

Schau, E.M., Fet, A.M., 2008. LCA studies of food products as background for environmental product declarations. Int. J. Life Cycle Assess. 13, 255-264.

SÉNAT, 2016. Lutter contre le gaspillage alimentaire (eng: Fight Against Food Waste) [Online]. The French Senate, Paris Available: http://www.senat.fr/espace:presse/ actualites/201601/lutter_contre_le_gaspillage_alimentaire.html (Accessed July 29, 2016).

SIDRA-IBGE. Tabela 99 [Online]. Sistema IBGE de Recuperação Automática (SIDRA). Instituto Brasileiro de Geografia e Estatística (IBGE). Available: http://www.sidra. ibge.gov.br [Accessed August 15, 2015].

SJV, 2015a. Bekämpningsrekommendationer, svampar och insekter 2015. Jönköping, Jordbruksverket.

SJV, 2015b. Kemisk ogräsbekämpning, våren 2015. Jönköping, Jordbruksverket.

SLU, 2015. Paths to a sustainable food sector (Hållbara Matvägar) [Online]. Project homepage. Swedish University of Agricultural Sciences Available: http://www.slu. se/sv/centrumbildningar-och-projekt/hallbara-matvagar/ (Accessed Dec 16, 2016).

SLU, 2016. Use of Pesticides [Online]. Centre for Chemical Pesticides, Swedish University of Agricultural Sciences, Uppsala Available: https://www.slu.se/en/CollaborativeCentres-and-Projects/centre-for-chemical-pesticides-ckb1/information-aboutpesticides-in-the-environment-/overview-of-pesticides-and-their-use/ (Accessed Dec 16, 2016).
Sonesson, U., Lorentzon, K., Florén, B., Krewer, C., Kumm, K.I., Nilsson, K., Woodhouse, A 2014. Hållbara matvägar - resultat och analys [Paths to a Sustainable Food Sector: Results and Analysis]. SIK-rapport 891 (In Swedish). The Swedish Institue for Food and Biotechnology (SIK), Gothenburg.

Sonesson, U.G., Lorentzon, K., Andersson, A., Barr, U.-K., Bertilsson, J., Borch, E., Brunius, C., Emanuelsson, M., Göransson, L., Gunnarsson, S., 2016. Paths to a sustainable food sector: integrated design and LCA of future food supply chains: the case of pork production in Sweden. Int. J. Life Cycle Assess. 21, 664-676.

Sonesson, U., Davis, J., Flysjö, A., Gustavsson, J., Witthöft, C., 2017. Protein quality as functional unit-a methodological framework for inclusion in life cycle assessment of food. J. Clean. Prod. 140, 470-478.

Souza, A.S.D., Torres, J.P.M., Meire, R.O., Neves, R.C., Couri, M.S., Serejo, C.S., 2008. Organochlorine pesticides (OCs) and polychlorinated biphenyls (PCBs) in sediments and crabs (Chasmagnathus granulata, Dana, 1851) from mangroves of Guanabara Bay, Rio de Janeiro State, Brazil. Chemosphere 73, S186-S192.

SOYSTATS, 2016. International: Adoption of Biotech Enhanced Seedstock [Online] SoyStats. Available: http://soystats.com/international-adoption-of-biotechenhanced-seedstock/ (Accessed August 10, 2016).

Stehle, S., Schulz, R., 2015. Agricultural insecticides threaten surface waters at the global scale. Proc. Natl. Acad. Sci. 112, 5750-5755.

Tilman, D., Clark, M., 2014. Global diets link environmental sustainability and human health. Nature 515, 518-522.

Uzogara, S.G., 2000. The impact of genetic modification of human foods in the 21st century: a review. Biotechnol. Adv. 18, 179-206.

Vallin, A., Grimvall, A., Sundblad, E.L., Djodjic, F., 2016. Changes in four societal drivers and their potential to reduce Swedish nutrient inputs into the sea. Report 2016:11. Gothenburg, Swedish Agency for Marine and Water Management.

Van Hoof, G., Schowanek, D., Franceschini, H., Muñoz, I., 2011. Ecotoxicity impact assessment of laundry products: a comparison of USEtox and critical dilution volume approaches. Int. J. Life Cycle Assess. 16 (8), 803-818.

Van Zelm, R., Huijbregts, M.A.J., Van De Meent, D., 2009. USES-LCA 2.0-a global nested multi-media fate, exposure, and effects model. Int. J. Life Cycle Assess. 14 (3), 282-284.

Van Zelm, R., Larrey-Lassalle, P., Roux, P., 2014. Bridging the gap between life cycle inventory and impact assessment for toxicological assessments of pesticides used in crop production. Chemosphere 100, 175-181.

Waichman, A.V., Eve, E., Celso da Silva Nina, N., 2007. Do farmers understand the information displayed on pesticide product labels? A key question to reduce pesticides exposure and risk of poisoning in the Brazilian Amazon. Crop. Prot. 26, 576-583.

Westhoek, H.J., Rood, G.A., van Den Berg, M., Janse, J.H., Nijdam, D.S., Reudink, M.A., Stehfest, E.E., 2011. The Protein Puzzle: The Consumption and Production of Meat, Dairy and Fish in the European Union. PBL Netherlands Environmental Assessment Agency, The Hague.

Whitehorn, P.R., O'connor, S., Wackers, F.L., Goulson, D., 2012. Neonicotinoid pesticide reduces bumble bee colony growth and queen production. Science 336, 351-352.

Wirsenius, S., Azar, C., Berndes, G., 2010. How much land is needed for global food production under scenarios of dietary changes and livestock productivity increases in 2030 ? Agric. Syst. 103, 621-638.

Yang, Y., Suh, S., 2015. Changes in environmental impacts of major crops in the US. Environ. Res. Lett. 10, 094016. 